\section{Encephalitis lethargica von Economo}

Helga Peter ${ }^{1}$ und Thomas Penzel ${ }^{2}$

${ }^{1}$ Marburg, Deutschland

${ }^{2}$ Interdisziplinäres Schlafmedizinisches Zentrum, Charité Universitätsmedizin Berlin, Berlin, Deutschland

\section{Englischer Begriff}

Economo's encephalitis

\section{Definition}

Viral ausgelöste Entzündung verschiedener Hirnareale, einschließlich des Hirnstamms und des Hypothalamus. Erstbericht im Jahre 1917, Auftreten in Epidemien bis 1927. Erstsymptome waren Stupor, exzessive Schläfrigkeit, gestörter Nachtschlaf sowie parkinsonartige Symptome mit generalisierter Rigidität und Bewegungsstörungen. Der österreichische Neurologe Constantin von Economo erkannte und beschrieb das Auftreten von drei unterschiedlichen Arten von Schlafstörungen: exzessive Schläfrigkeit, Insomnie und Schlafumkehr. 